\title{
PERANCANGAN KONVERTER ARUS SEARAH TIPE BUCK CONVERTER DENGAN UMPAN BALIK (FEEDBACK) MENGGUNAKAN IC TL494 SEBAGAI STABILITAS TEGANGAN PENGISIAN BATERAI
}

\author{
Adya Pradipta*), Mochammad Facta dan Sudjadi \\ Departemen Teknik Elektro, Universitas Diponegoro \\ Jl. Prof. Sudharto, SH, Kampus UNDIP Tembalang, Semarang 50275, Indonesia \\ ${ }^{*}$ E-mail: adyapradipta007@gmail.com
}

\begin{abstract}
Abstrak
Sumber listrik DC banyak dikembangkan di berbagai sektor, terutama kelistrikan dan otomotif. Hal ini dampak dari inovasi perkembangan teknologi yang sangat pesat khususnya pada perangkat dengan basis sumber listrik DC. Baterai dan perangkat elektronik adalah perangkat berbasis listrik DC yang banyak dikembangkan dan membutuhkan suplai tegangan yang stabil. Jika tegangan tidak stabil maka membuat perangkat menjadi rusak. Peran regulator stabilitas tegangan sangat penting pada perangkat berbasis listrik DC. Permasalahan tersebut dibahas dalam penelitian ini menggunakan buck converter sebagai stabilitas tegangan untuk pengisian baterai. Pada penelitian ini, dilakukan dua pengujian yaitu tanpa umpan balik tegangan dan dengan umpan balik tegangan. Hasil pengujian konverter tanpa umpan balik tegangan pada variasi tegangan masukan $30 \mathrm{~V}$ memiliki penurunan tegangan dari beban $390 \Omega$ ke $50 \Omega$ sebesar $5,528 \mathrm{~V}$. Kemudian pengujian konverter dengan umpan balik tegangan, nilai tegangan keluaran dapat dijaga konstan sebesar 13,8 V dengan variasi beban $390 \Omega$ ke $50 \Omega$ dan deviasi rata-rata 0,001 volt. Efisiensi rata - rata buck converter dengan umpan balik tegangan pada variasi beban $390 \Omega$ ke $50 \Omega$ adalah 70,094\%. Pengujian menggunakan kontrol umpan balik tegangan pada konverter arus searah tipe buck converter menghasilkan nilai tegangan yang lebih stabil dibandingkan pengujian konverter tanpa umpan balik tegangan.
\end{abstract}

Kata kunci : Listrik DC, Baterai, Buck Converter, IC TL494

\begin{abstract}
Direct Current power sources are being developed in various sectors, especially in sector of electricity and automotive. This is the impact of very rapid technological development innovations, especially for devices with DC power source. Batteries and electronic devices are DC-based electric devices that widely developed and they require a stable voltage supply. If the voltage is unstable then the device can be damaged. The presence of the voltage stability regulator is very important in DC electric devices. The problem discussed in this study uses buck converter as voltage stability for battery charging. In this study, two tests are carried out without voltage feedback and voltage feedback. Test results of converter without voltage feedback, at the input voltage $30 \mathrm{~V}$, the result give a voltage drop $5.528 \mathrm{~V}$ for variation $390 \Omega$ to $50 \Omega$ resistive load. Test resultf of converter with voltage feedback, the output voltage can be maintained constantly at $13.8 \mathrm{~V}$ with variation in load and the average deviation 0.001 volts. The average efficiency of buck converter with voltage feedback at variation load $390 \Omega$ to $50 \Omega$ is $70,094 \%$. In conclusiong a voltage feedback control for a buck converter type produces more stable voltage than the converter without voltage feedback.
\end{abstract}

Keywords: DC Electricity, Battery, Buck Converter, IC TL494

\section{Pendahuluan}

Listrik Direct Current (DC) adalah teknologi listrik yang cukup pesat dengan salah satu aspek yang perkembangannya sangat signifikan adalah elektronika daya. Elektronika daya merupakan ilmu di dunia elektro yang merekayasa elektronika dengan mengkombinasikan dengan rangkaian daya atau sistem tenaga listrik. Elektronika daya merupakan teknologi yang memungkinkan untuk mencapai konversi tenaga listrik dari satu bentuk ke bentuk lain, memungkinkan kombinasi perangkat semikonduktor dengan sistem tenaga listrik daya tinggi dan menggunakan komponen pasif terutama transformer, induktor, dan kapasitor [1]. Dibanding dengan regulator linear, elektronika daya lebih efisien untuk konversi dan banyak digunakan dalam regulator karena rugi - rugi daya yang kecil dan cocok untuk konversi daya rendah maupun daya tinggi [2]. Elektronika daya banyak dimanfaatkan pada perangkat elektronik seperti audio, di 
sistem tenaga listrik, baterai, TV, komputer, handphone dan lain-lain. Baterai adalah sebuah alat yang dapat merubah energi kimia yang disimpannya menjadi energi listrik DC yang digunakan pada perangkat elektronik. Baterai tersusun dari satu atau lebih sel, masing masing sel terdapat elektrode positif, elektrode negatif, separator dan elektrolit [3]. Baterai banyak digunakan dalam berbagai aplikasi, seperti aplikasi bidang telekomunikasi, perangkat elektronik, sistem alarm kebakaran, panel surya, bahkan untuk aplikasi medis [4]. Pengisian baterai harus memiliki nilai tegangan yang stabil dan tidak boleh melebihi batas arus yang ditentukan. Nilai tegangan yang berubah-ubah dapat menyebabkan timbul panas pada baterai, yang menyebabkan berkurangnya umur (lifetime) dari baterai tersebut[5].

Untuk mengatasi permasalahan stabilitas tegangan pengisian baterai, maka pada Penelitian ini akan membahas stabilitas tegangan pengisian baterai dengan rangkaian buck converter yang diumpan balik (feedback) tegangan. Sehingga tegangan keluaran dari buck converter memiliki nilai tegangan yang stabil walaupun tegangan inputan berubah-ubah. Implementasi penelitian ini dengan perancangan konverter arus searah tipe buck converter dengan sistem kontrol menggunakan IC TL 494 dan driver switching MOSFET menggunakan TLP 250. Sebelum memulai perancangan terlebih dahulu mencari komponen yang dibutuhkan dan menghitung nilai komponen sebelum dilakukan simulasi menggunakan software PSIM untuk memastikan sistem sudah berjalan sesuai perencanaan yaitu dapat menghasilkan tegangan keluaran konverter yang lebih kecil dari tegangan inputannya dengan variasi duty cycle [6].

\section{Metode}

Perancangan buck converter sebagai stabilitas tegangan pengisian baterai terbagi menjadi 3 sub sistem, yaitu kontrol sinyal PWM, MOSFET driver, dan rangkaian daya buck converter. Blok diagram sistem ditunjukkan pada Gambar 1.

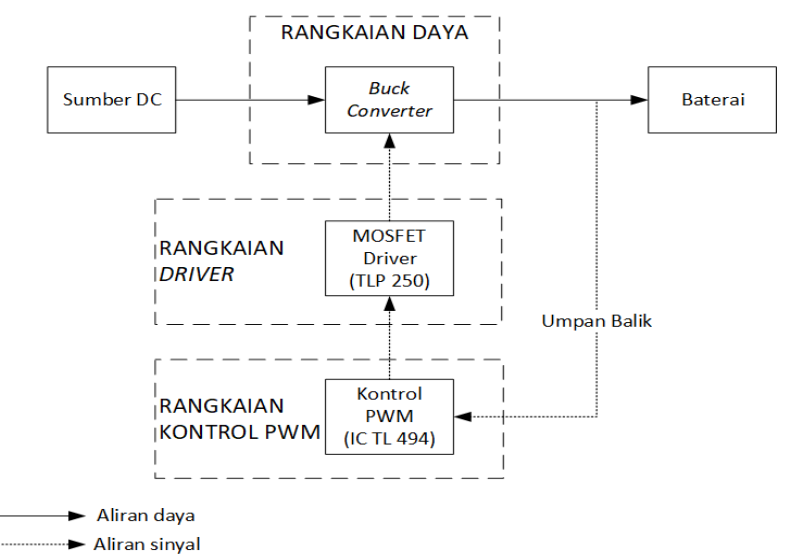

Gambar 1. Blok diagram system

\subsection{Perancangan Buck Converter}

Rangkaian daya dalam penelitian ini mengguanakan buck converter yang berfungsi penurun tegangan yang mengkonversi tegangan masukan DC menjadi tegangan DC lainya yang lebih rendah. Buck converter diatur tegangan keluarannya menggunakan dua mode yaitu dengan umpan balik (feedback) tegangan dan tanpa umpan balik tegangan. Pemilihan buck converter pada penelitian ini karena fungsinya sebagai penurun tegangan sekaligus sebagai stabilitas tegangan untuk pengisian baterai. Spesifikasi buck converter ditunjukkan pada Tabel 1.

Tabel 1. Parameter Perencanaan buck converter

\begin{tabular}{cc}
\hline Spesifikasi & Nilai / Keterangan \\
\hline Tegangan Masukan & $30 \mathrm{~V}$ \\
Tegangan keluaran & $13,8 \mathrm{~V}$ \\
Arus Keluaran & $3 \mathrm{~A}$ \\
\hline
\end{tabular}

Terdapat 4 komponen utama dalam buck converter yaitu dioda, induktor, kapasitor, Metal Oxide Semiconductor Field Effect Transistor (MOSFET) dan resistor sebagai beban. MOSFET digunakan sebagai komponen switching yang dikontrol menggunakan PWM.

Tabel 2. Komponen rangkaian buck converter

\begin{tabular}{cc}
\hline Komponen & Tipe / Nilai \\
\hline MOSFET & IRFP260N \\
Dioda & MUR460 \\
Induktor & $1,3 \mathrm{mH}$ \\
Kapsitor & $470 \mu \mathrm{F} / 100 \mathrm{~V}$ \\
\hline
\end{tabular}

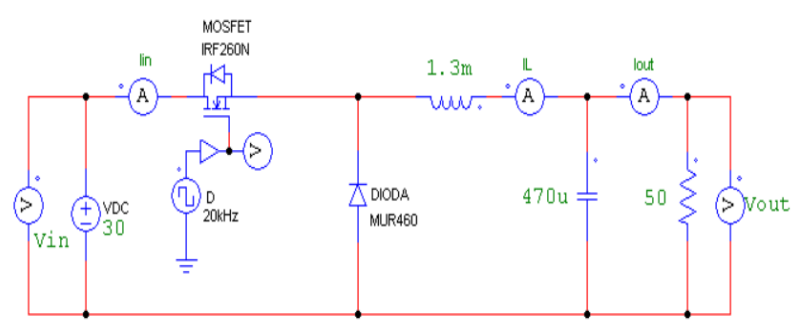

(a) Simulasi rangkaian buck converter dengan PSIM

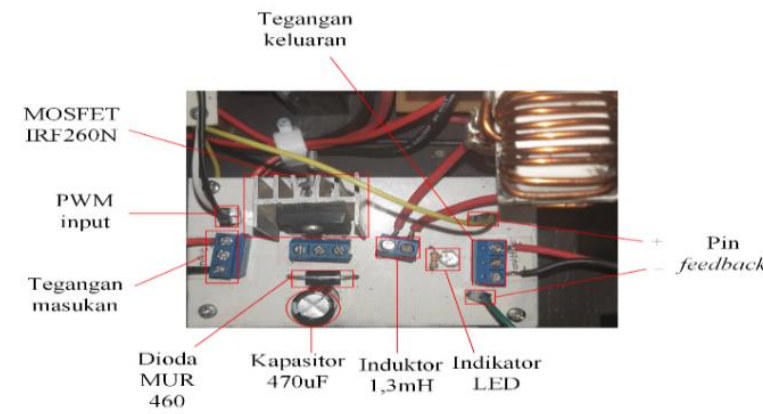

(b) Realisasi rangkaian buck converter 


\subsection{Perencanaan Rangkaian Kontrol IC TL494}

Konverter arus searah dapat dikendalikan tegangan keluarannya dengan rangkaian kontrol. Untuk mengontrol konverter tersebut digunakan rangkaian pengontrol yang menghasilkan gelombang PWM sebagai masukan bagi MOSFET sehingga keluaran tegangan konverter dapat diatur. IC TL494 adalah salah satu rangkaian kontrol pembangkit PWM yang terintegrasi dalam satu chip untuk memicu MOSFET.

Pada penelitian ini PWM dibangkitkan dari IC TL494 dan dikuatkan dengan rangkaian driver. IC TL494 dirancang dapat menggunakan umpan balik (feeedback) dengan memanfaatkan fitur error amplifier dan tanpa umpan balik dengan mengatur tegangan masukan ke PIN 4 pada range $0-3,3$ V. Peralihan dari mode umpan balik (feedback) ke mode tanpa umpan balik dirancang menggunakan 2 saklar SPDT (Single Pole Double Throw).

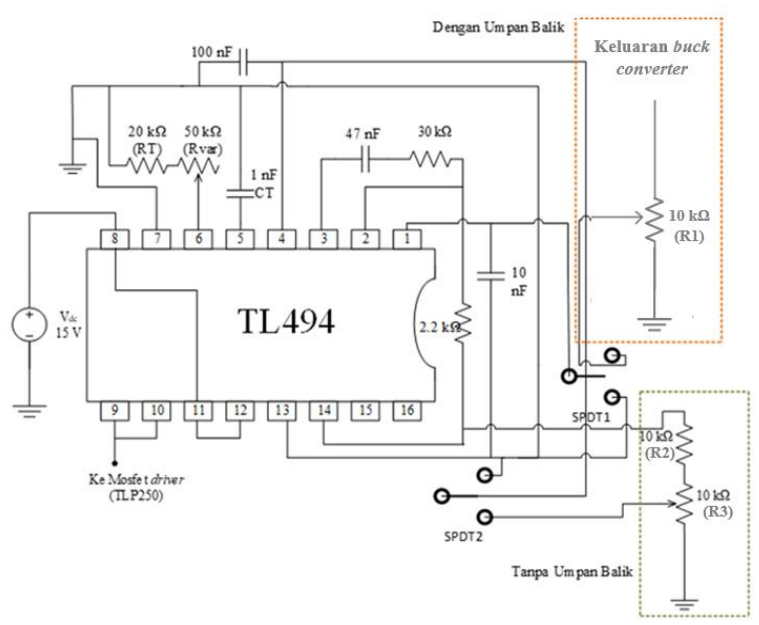

Gambar 3. Rangkaian IC TL494 dengan umpan balik tegangan dan tanpa umpan balik tegangan

Untuk mengatur nilai frekuensi osilasi pada IC TL494 diatur oleh dua komponen yang terdapat pada Pin 5 dan Pin 6. Komponen pada Pin 5 terdapat Resistor Timer (RT) dan Pin 6 terdapat Capacitor Timer (CT). Untuk menghitung besar nilai frekuensi osilasi $(f s)$ maksimal dari rangkaian PWM menggunakan persamaan 1 sebagai berikut :

$$
f_{S}=\frac{1,1}{R_{T} \cdot C_{T}}
$$

Besar nilai komponen yang digunakan adalah :

$$
\begin{aligned}
& C_{T}=1 \mathrm{nF} / 50 \mathrm{~V} \\
& R_{T}=20 \mathrm{k} \Omega / 1 \mathrm{~W} \\
& R_{\text {Var }}=50 \mathrm{k} \Omega
\end{aligned}
$$

Setelah nilai resistor dan kapasitor ditentukan, kemudian menentukan nilai frekuensi osilasi maksimal dan minimal.

$$
f_{S(\max )}=\frac{1,1}{20000 \times 1 \times 10^{-9}}
$$

$$
\begin{aligned}
& =55 \mathrm{kHz}(\text { RVar }=0 \Omega) \\
f_{s(\min )} & =\frac{1,1}{70000 \times 1 \times 10^{-9}} \\
& =15714 \mathrm{~Hz}(\text { RVar }=50 \mathrm{k} \Omega)
\end{aligned}
$$

Pada perancangan IC TL494 frekuensi osilasi yang digunakan adalah $20 \mathrm{KHz}$. Frekuensi ini didapat dengan pengaturan potensiometer $\left(\mathrm{R}_{V A R}\right) 50 \mathrm{k} \Omega$. Duty cycle dapat diatur dengan mengatur potensiometer (R3) $10 \mathrm{~K} \Omega$ sehingga bekerja pada mode tanpa umpan balik. Dan untuk mengatur set point pada mode umpan balik digunakan potensiometer (R1) $10 \mathrm{~K} \Omega$, sehingga besar kecilnya duty cycle akan secara otomatis mengatur sendirinya untuk membuat tegangan keluaran konstan. Keluaran dari IC TL494 berupa gelombang PWM adalah Pin 9 disambung Pin 10 yang disatukan. Duty cycle yang dirancang pada rangkaian kontrol IC TL494 ini diatur dengan range sebesar $10 \%-90 \%$.

Tabel 3. Parameter rangkaian control IC TL494 [7]

\begin{tabular}{cc}
\hline Parameter & Nilai Besaran \\
\hline Suplai Vcc & $15 \mathrm{~V}$ \\
Duty cycle & $10 \%-90 \%$ \\
Frekuensi & $15 \mathrm{kHz}-55 \mathrm{kHz}$ \\
\hline
\end{tabular}

\subsubsection{Perancangan Tanpa Umpan Balik Tegangan}

Perancangan tanpa umpan balik pada IC TL494 menggunakan tegangan masukan pada Pin 4 dengan range sebesar $0-3,3 \mathrm{~V}$ [7]. Duty cycle diatur menggunakan potensiometer (R3) $10 \mathrm{k} \Omega$. Rangkaian IC TL494 tanpa umpan balik tegangan ditunjukkan pada Gambar 4. sebagai berikut :

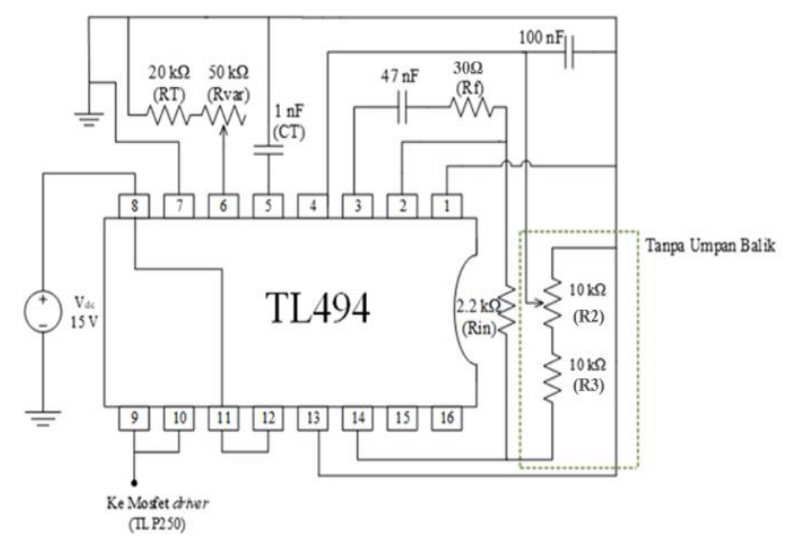

Gambar 4. Rangkaian IC TL494 tanpa umpan balik tegangan

Gambar 4. merupakan rangkaian IC TL494 dengan mode tanpa umpan balik. Pada Pin 4 mendapat sumber tegangan dari Pin 14 sebesar 5V yang kemudian melewati R2 dan R3 sebagai pembagi tegangan. R3 merupakan potensiometer sebesar $10 \mathrm{k} \Omega$ yang berguna untuk mengatur duty cycle rentanng $10 \%$ - 90\%, penambahan resisitor R2 bergunan untuk membatasi duty cycle menyentuh $0 \%$. 


\subsubsection{Perancangan dengan Umpan Balik Tegangan}

Perancangan dengan umpan balik tegangan atau feedback berfungsi agar tegangan keluaran buck converter stabil pada tegangan yang diatur (set point). Umpan balik ini memiliki prinsip kerja pembagi tegangan (voltage divider), sehingga hasil pembagi tegangan tersebut digunakan sebagai pengoreksi antara tegangan keluaran konverter dengan tegangan referensi. Rangkaian IC TL494 dengan umpan balik tegangan ditunjukkan pada gambar 5. sebagai berikut :

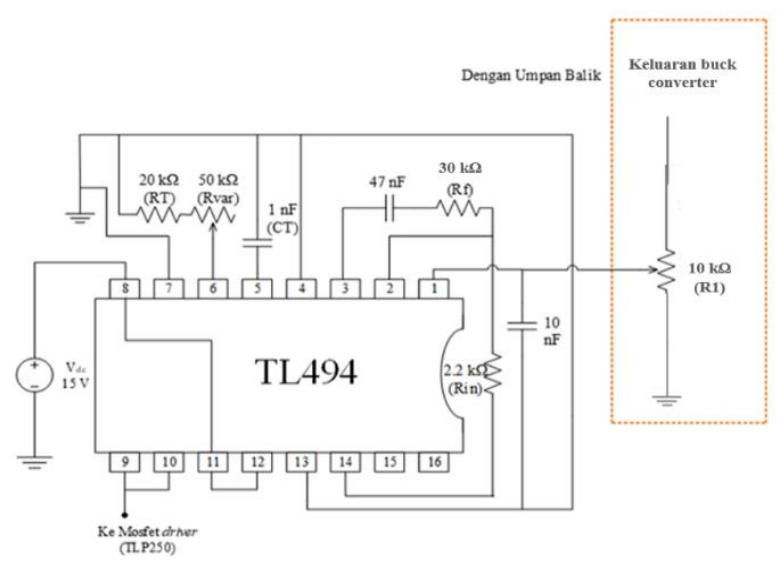

Gambar 5. Rangkaian IC TL494 dengan umpan balik tegangan

Gambar 5. merupakan rangkaian IC TL494 dengan umpan balik tegangan. Keluaran buck converter masuk ke rangkaian voltage divider (R1) sebagai penurun tegangan dan menjadi masukan Pin 1 (noninverting), sehingga tegangan bisa di bandingkan dengan tegangan referensi yang terdapat di Pin 2 (inverting). Pin 1 dan Pin 2 adalah masukan bagi error amplifier yang berfungsi sebagai pembanding inverting dan noninverting untuk menghasilkan nilai duty cycle yang diperlukan sehingga tegangan keluaran stabil pada set point yang telah ditentukan. Pada Gambar 5. terdapat resistor sebesar 2,2 $\mathrm{k} \Omega(\mathrm{Ri})$ dan $30 \mathrm{k} \Omega(\mathrm{Rf})$ yang berguna untuk memberikan gain (A) pada keluaran error amplifier. Untuk mencari nilai tegangan keluaran error amplifier $\left(\mathrm{V}_{\mathrm{e}}\right)$ menggunakan persamaan (2) sebagai berikut :

Dimana :

$$
V_{e}=A\left(V_{1}-V_{2}\right)
$$

$V_{e} \quad=$ tegangan keluaran error amplifier $(\mathrm{V})$

$A=$ gain

$V_{1} \quad=$ tegangan noninverting atau pin $1(\mathrm{~V})$

$V_{2} \quad=$ tegangan inverting atau pin $2(\mathrm{~V})$

Untuk menghitung gain (A) menggunakan persamaan (3) sebagai berikut :

$$
A=1+\frac{R_{f}}{R_{i}}
$$

Realisasi rangkaian kontrol PWM IC TL494 ditunjukkan pada Gambar 6. sebagai berikut :

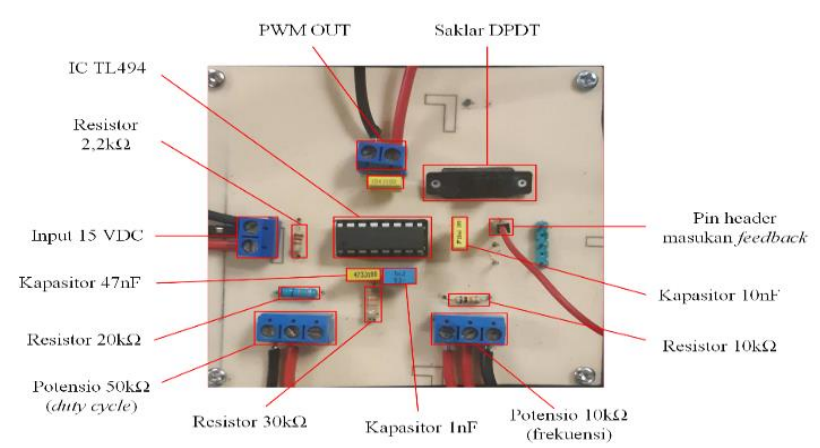

Gambar 6. Realisasi rangkaian IC TL494

\subsection{Perancangan Rangkaian Driver TLP250}

Rangkaian TLP 250 digunakan untuk mengisolasi dan menguatkan sinyal PWM level tegangan 5 volt yang dibangkitkan IC TL494 menjadi level tegangan yang lebih tinggi dengan sistem ground terpisah (level tegangan 15V) dan cukup untuk memicu MOSFET IRP260N pada buck converter yang membutuhkan tegangan VGS $\pm 20 \mathrm{~V}$. Optocoupler TLP250 memiliki waktu switching yang sangat cepat, yaitu waktu tunda pada saat kondisi Low ke High sebesar $0,15 \mu \mathrm{s}$ maksimal $0,5 \mu \mathrm{s}$ dan sebaliknya. Tegangan suplai masukan minimum TLP250 sebesar 10 volt dan maksimumnya 35 volt.

Arus maksimal masukan Photodiode (If) yang di ijinkan berdasarkan datasheet TLP250 [8] yaitu $20 \mathrm{~mA}$, sehingga dapat dihitung nilai resistansi resistor minimum $\left(\mathrm{R}_{\mathrm{MIN}}\right)$ yang diperlukan adalah

$$
R_{M I N}=\frac{V_{I N}-V_{f}}{I_{f}}
$$

Dengan nilai tegangan masukan $\left(\mathrm{V}_{\mathrm{IN}}\right)$ adalah $15 \mathrm{~V}$ (level tegangan PWM). Tegangan photodiode (Vf) adalah $1,6 \mathrm{~V}$ dan menggunakan asumsi awal If $=20 \mathrm{~mA}$.

$$
R_{M I N}=\frac{15-1,6}{0,02}=670 \Omega
$$

Nilai resistansi minimum yang dibutuhkan adalah $665 \Omega$. Pada realisasinya dipilih resistor dengan nilai diatas $665 \Omega$ yaitu $1 \mathrm{k} \Omega$. Maka nilai If akan berubah, sehingga dicari nilai If dengan persamaan 4.

$$
\begin{aligned}
I_{f} & =\frac{15-1,6}{R_{M I N}} \\
I_{f} & =\frac{13,4}{1000} \\
I_{f} & =13,4 \mathrm{~mA}
\end{aligned}
$$

Dengan nilai arus photodiode (If) 13,4 mA maka TLP250 sudah dapat berfungsi dengan baik $(<20 \mathrm{~mA})$. Pada rangkaian juga terdapat kapasitor bypass $100 \mathrm{nF}$ antara power supply IC dengan ground output sesuai datasheet [8] yang berfungsi untuk menstabilkan operasi dari penguat linier berpenguatan tinggi. 


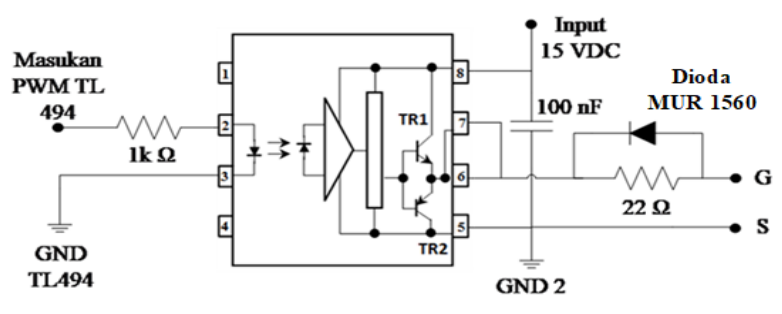

Gambar 7. Rangkaian skematik TLP 250

Antara ground IC TL494 dan ground TLP 250 harus terpisah karena akan berdampak pada short circuit yang akan terjadi pada rangkaian buck converter. Ground TL494 adalah ground dari rangkaian kontrol IC TL494, sedangkan ground 2 adalah ground dari rangkaian TLP250.

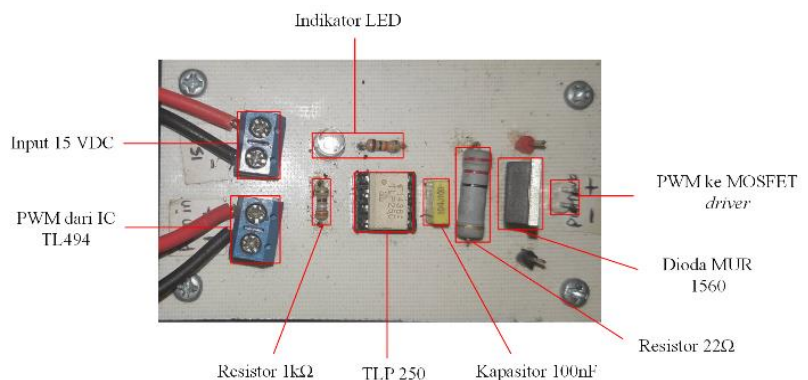

Gambar 8. Realisasi rangkaian MOSFET driver TLP250

\section{Hasil dan Analisis \\ 3.1. Pengujian Rangkaian Kontrol Pembangkit Sinyal PWM IC TL494}

Rangkaian pembangkit PWM pada penelitian ini menggunakan IC TL494 dengan satu keluaran (singleended operation). Pengujian rangkaian IC TL494 ini bertujuan untuk mengetahui nilai tegangan keluaran dan gelombang output PWM yang dirancang pada frekuensi 20 $\mathrm{kHz}$ dengan variasi duty cycle. Keluaran IC TL494 berada pada Pin 9 dan Pin 10 yang disatukan untuk mendapatkan satu keluaran (single-ended)

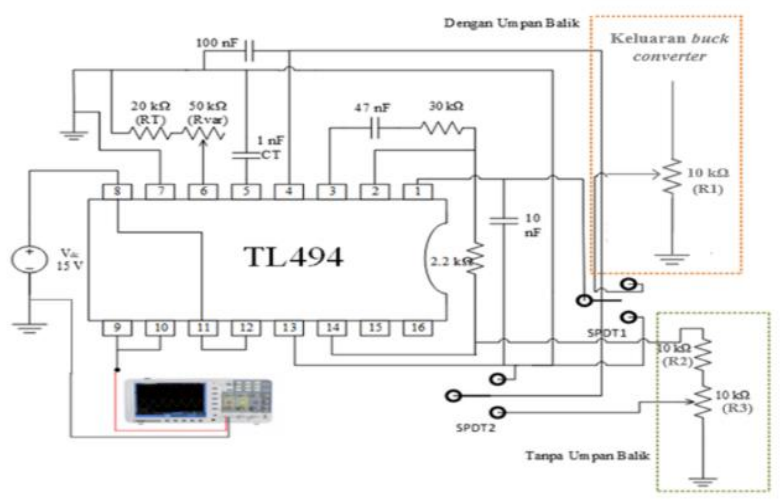

Gambar 9. Skema pengujian rangkaian PWM IC TL494
Pengujian PWM IC TL494 dilakukan pada duty cycle 50\%, yang kemudian dihitung nilai tegangan keluaran, frekuensi dan duty cycle pada gelombang yang terbaca pada osiloskop. Dengan menggunakan persamaan 5. untuk mencari nilai duty cycle sebagai berikut :

$$
D=\frac{T_{o n}}{T_{o n}+T_{o f f}} \times 100 \%
$$

Dimana :

$D=$ Duty cycle $(\%)$

$T_{\text {on }}$ = waktu gelombang high

$T_{\text {off }}=$ waktu gelombang low

Kemudian untuk mencari tegangan keluaran menggunakan persamaan 6. sebagai berikut :

$$
V=\frac{V}{d i v} \times d i v
$$

Dimana :

$\mathrm{V}$ = Tegangan $(\mathrm{V})$

$\frac{V}{d i v}=$ tegangan persatuan $\operatorname{kotak}(\mathrm{V})$

div $=$ jumlah kotak

Nilai waktu (T) diperoleh dengan menjumlahkan kotak pada suatu gelombang.

$$
\begin{aligned}
& T=\frac{\text { time }}{\text { div }} \times \text { div } \\
& T \quad=\text { perioode }(\mathrm{s}) \\
& \frac{\text { time }}{d i v}=\text { waktu persatuan } \operatorname{kotak}(\mathrm{s}) \\
& \text { div }=\text { jumlah kotak }
\end{aligned}
$$

Dengan menggunakan persamaan (8) maka didapatkan nilai frekuensi :

$$
f=\frac{1}{T}
$$

Dimana :

$f \quad=$ frekuensi $(\mathrm{Hz})$

$\mathrm{T} \quad=$ periode $(\mathrm{s})$

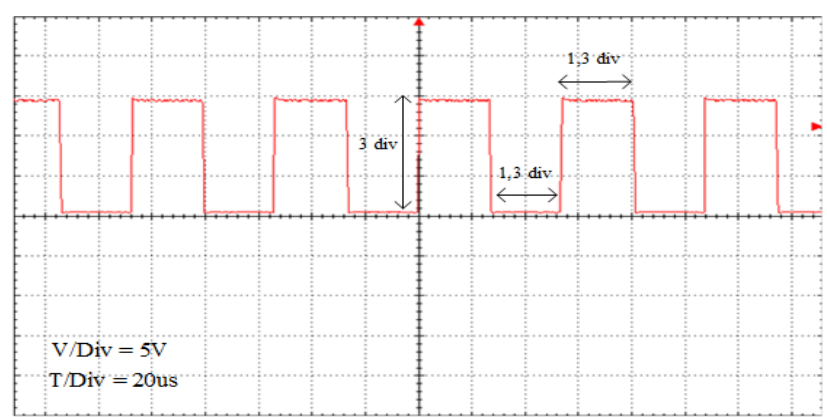

\section{Gambar 10. Gelombang keluaran PWM 50\% IC TL494}

Gambar 10. merupakan gelombang keluaran PWM dengan duty cycle $50 \%$ yang dihasilkan oleh IC TL494. Dengan menggunakan persamaan (5), (6), (7), (8) didapatkan nilai: duty cycle $=50 \%$, tegangan keluaran $=15 \mathrm{~V}$, frekuensi $=$ $19230 \mathrm{~Hz}$. 


\subsection{Pengujian Rangkaian MOSFET driver TLP250}

Rangkaian MOSFET driver TLP250 pada penelitian ini digunakan sebagai penguat sinyal PWM keluaran dari rangkaian kontrol IC TL494 dan pemisah antara rangkaian kontrol dan rangkaian daya.

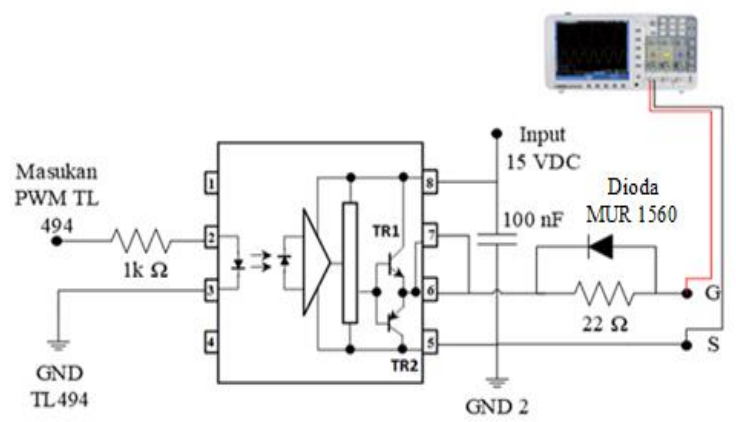

Gambar 11. Skema pengujian rangkaian MOSFET driver TLP250

Pengujian rangkaian MOSFET Driver TLP250 dilakukan menggunakan osiloskop OWON 1 channel yang dihubungkan pada kaki 6 atau kaki 7 sebagai keluaran TLP250 dengan titik ground kaki 5 TLP250. Terdapat kapasitor sebesar 100nF. Kapasitor ini adalah kapasitor bootstrap yang berfungsi sebagai Recharging Current untuk mengatasi floating ground pada rangkaian buck converter. Pengujian pada TLP 250 sama dengan pengujian rangkaian kontrol PWM IC TL494.

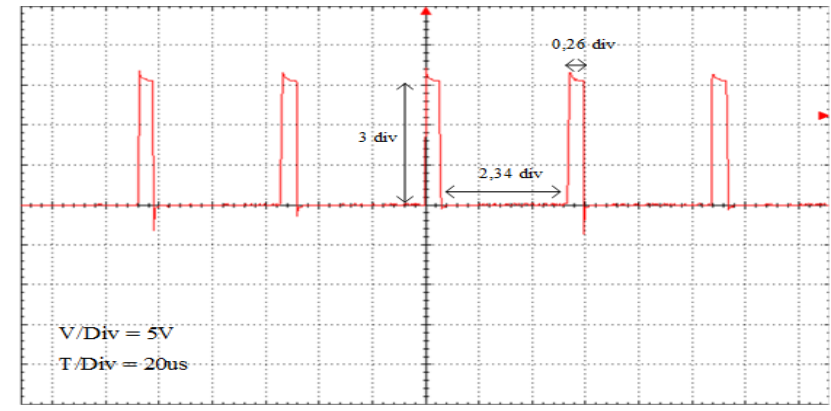

Gambar 12. Gelombang sinyal PWM keluaran TLP250

Dengan menggunakan persamaan (5), (6), (7), (8) didapatkan nilai:

duty cycle $=50 \%$, tegangan keluaran $=15 \mathrm{~V}$, frekuensi $=$ $19230 \mathrm{~Hz}$.

\subsection{Pengujian Rangkaian Konverter Arus Searah tipe Buck}

Pengujian rangkaian konverter arus searah buck converter meliputi dari pengujian tegangan keluaran konverter arus searah buck converter tanpa umpan balik tegangan serta dengan umpan balik tegangan (feedback). Pengujian buck converter bertujuan untuk mengetahui bahwa tegangan keluaran dari buck converter sudah sesuai yaitu tegangan masukan lebih besar dari tegangan keluaran dan mengetahui efisiensi dari rangkaian buck converter yang telah dibuat.

\subsubsection{Pengujian Keluaran Rangkaian Buck Converter Tanpa Umpan Balik}

Skema pengujian konverter arus searah buck converter kondisi tanpa umpan balik tegangan ditunjukkan pada Gambar 13.

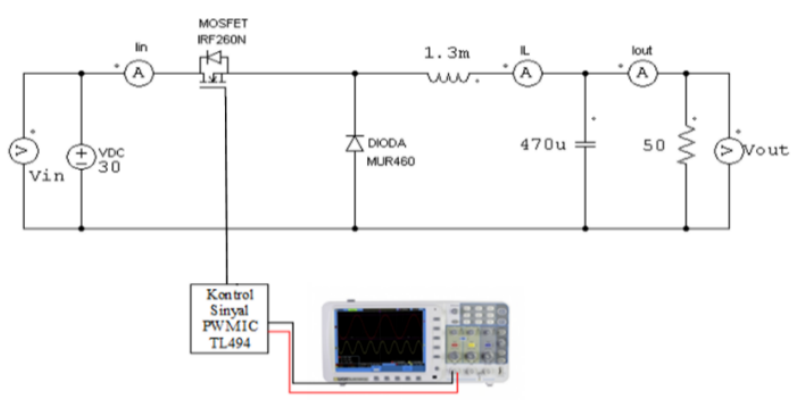

Gambar 13. Pengujian tegangan keluaran konverter arus searah buck converter tanpa umpan balik tegangan

Pengujian tanpa umpan balik tegangan (feedback), tegangan disetting pada nilai $30 \mathrm{~V}$ yang merupakan tegangan masukan maksimal untuk menghasilkan tegangan keluaran 13,8V dengan duty cycle sebesar $25,3 \%$ dengan beban resistif yang digunakan sebesar $390 \Omega$ yang merupakan beban maksimal dalam pengujian ini. Tujuan pengujian tanpa umpan balik tegangan ini dilakukan untuk mengetahui respon tegangan keluaran dan arus keluaran konverter arus searah buck converter terhadap variasi beban resistif dari $390 \Omega$ sampai $50 \Omega$.

Tabel 4. Pengujian konverter arus searah buck converter tanpa umpan balik tegangan, tegangan masukan 30V

\begin{tabular}{cccccc}
\hline $\begin{array}{c}\text { Beban } \\
(\boldsymbol{\Omega})\end{array}$ & $\begin{array}{c}\text { Vin } \\
(\mathrm{V})\end{array}$ & lin $(\mathrm{A})$ & Vout $(\mathrm{V})$ & lout $(\mathrm{A})$ & $\begin{array}{c}\text { Duty cycle } \\
(\%)\end{array}$ \\
\hline 390 & 30 & 0,0229 & 13,803 & 0,0357 & 25,3 \\
330 & 30 & 0,0245 & 13,303 & 0,0396 & 25,3 \\
270 & 30 & 0,0265 & 12,520 & 0,0471 & 25,3 \\
200 & 30 & 0,0301 & 11,529 & 0,0591 & 25,3 \\
180 & 30 & 0,0311 & 11,309 & 0,0625 & 25,3 \\
120 & 30 & 0,0371 & 10,231 & 0,0830 & 25,3 \\
100 & 30 & 0,0413 & 9,721 & 0,0969 & 25,3 \\
69 & 30 & 0,0525 & 8,851 & 0,1318 & 25,3 \\
50 & 30 & 0,0654 & 8,275 & 0,1662 & 25,3 \\
\hline
\end{tabular}




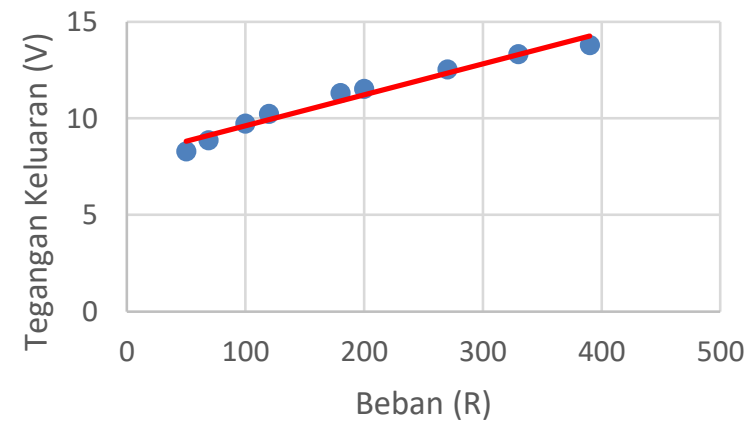

Gambar 14. Hubungan beban reisitif dengan tegangan keluaran konverter tanpa umpan balik tegangan, tegangan masukan $30 \mathrm{~V}$

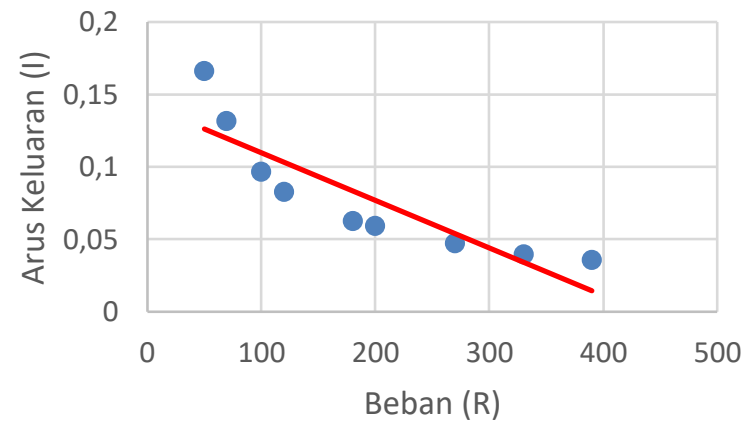

Gambar 15. Hubungan beban reisitif dengan arus keluaran konverter tanpa umpan balik tegangan, tegangan masukan $30 \mathrm{~V}$

\subsubsection{Pengujian Keluaran Rangkaian Buck Converter Dengan Umpan Balik}

Skema pengujian konverter arus searah buck converter kondisi tanpa umpan balik tegangan ditunjukkan pada Gambar 20.

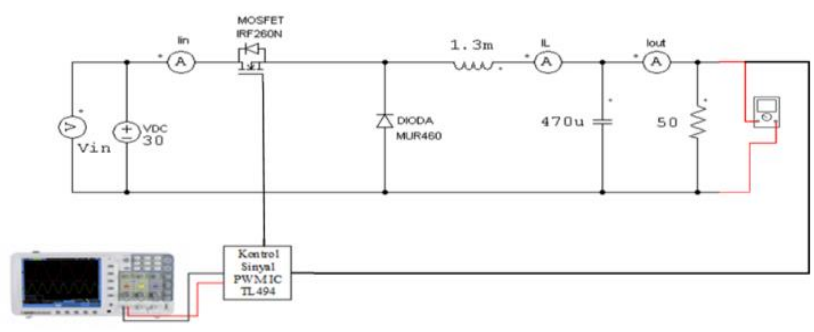

Gambar 16. Pengujian tegangan keluaran rangkaian buck converter dengan umpan balik tegangan

Pengujian dengan umpan balik tegangan (feedback) disetting pada tegangan keluaran $13,8 \mathrm{~V}$ dengan beban tegangan masukan 24V. Pengujian ini dilakukan untuk mengetahui respon tegangan keluaran dan arus keluaran buck converter dengan umpan balik terhadap perubahan beban variasi $390 \Omega$ sampai $50 \Omega$.
Tabel 5. Pengujian rangkaian buck converter dengan umpan balik tegangan, tegangan keluaran 13,8V

\begin{tabular}{cccccc}
\hline $\begin{array}{c}\text { Beban } \\
(\mathbf{\Omega})\end{array}$ & $\begin{array}{c}\text { Vin } \\
(\mathbf{V})\end{array}$ & Iin (A) & $\begin{array}{c}\text { Vout } \\
(\mathbf{V})\end{array}$ & Iout (A) & $\begin{array}{c}\text { Duty cycle } \\
(\boldsymbol{\%})\end{array}$ \\
\hline 390 & 24 & 0,0255 & 13,833 & 0,0356 & 35,9 \\
330 & 24 & 0,0306 & 13,834 & 0,0419 & 38,2 \\
270 & 24 & 0,0385 & 13,836 & 0,0516 & 41,7 \\
200 & 24 & 0,0541 & 13,837 & 0,0709 & 45,6 \\
180 & 24 & 0,059 & 13,836 & 0,0761 & 46,6 \\
120 & 24 & 0,088 & 13,835 & 0,1102 & 50,5 \\
100 & 24 & 0,108 & 13,835 & 0,1354 & 52,4 \\
68 & 24 & 0,161 & 13,834 & 0,1984 & 54,3 \\
50 & 24 & 0,220 & 13,834 & 0,2676 & 57,4 \\
\hline
\end{tabular}

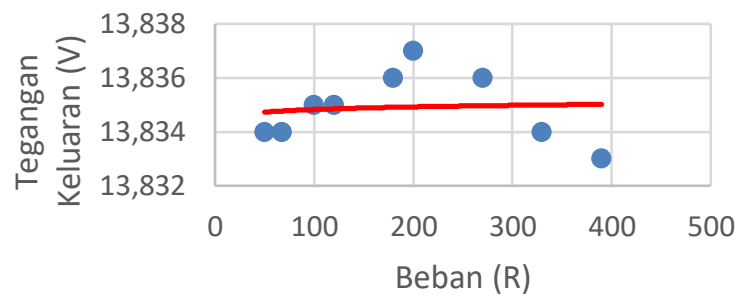

Gambar 17. Hubungan beban resistif dengan tegangan keluaran dengan umpan balik tegangan, tegangan keluaran 13,8 V

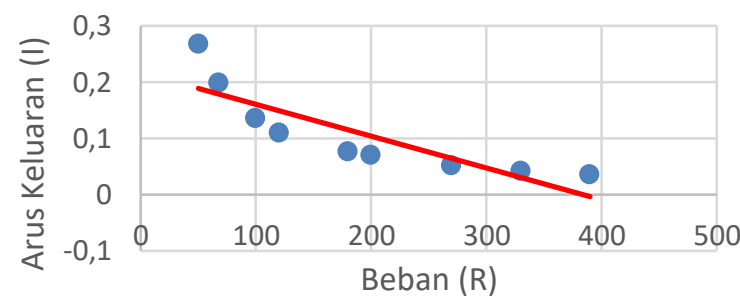

Gambar 18. Hubungan beban resistif dengan arus keluaran dengan umpan balik tegangan, tegangan keluaran 13,8V

\subsubsection{Perhitungan Efisiensi Konverter Arus Searah Buck Converter}

Efisiensi konverter arus searah buck converter dengan umpan balik dapat dicari dengan menghitung perbandingan daya input (Pin) dan daya output (Pout) dengan variasi beban antara $390 \Omega$ hingga $50 \Omega$, dengan menggunakan Persamaan (9) berikut.

$$
\eta=\frac{P_{\text {OUT }}}{P_{I N}} \times 100 \%
$$

Dimana :

$\eta \quad=$ efisiensi $(\%)$

$P_{I N}=V_{I N} \times I_{I N}$

$P_{\text {OUT }}=V_{\text {OUT }} \times I_{\text {OUT }}$ 
TRANSIENT, VOL. 7, NO. 4, DESEMBER 2018, ISSN: 2302-9927, 940

Tabel 6. Perhitungan efisiensi buck converter dengan umpan balik tegangan variasi beban resistif

\begin{tabular}{cccccccccc}
\hline $\begin{array}{c}\text { Beban } \\
(\boldsymbol{\Omega})\end{array}$ & $\begin{array}{c}\text { Vin } \\
(\mathrm{V})\end{array}$ & $\begin{array}{c}\text { lin } \\
(\mathrm{A})\end{array}$ & $\begin{array}{c}\text { Vout } \\
(\mathrm{V})\end{array}$ & $\begin{array}{c}\text { lout } \\
(\mathrm{A})\end{array}$ & $\begin{array}{c}\text { Duty } \\
\text { cycle } \\
(\%)\end{array}$ & $\begin{array}{c}\text { Pin } \\
(\mathbf{W})\end{array}$ & $\begin{array}{c}\text { Pout } \\
(\mathbf{W})\end{array}$ & $\begin{array}{c}\text { Efisiensi } \\
(\%)\end{array}$ & {$[1]$} \\
\hline 390 & 24 & 0,02 & 13,83 & 0,03 & 35,9 & 0,61 & 0,49 & 80,39 & \\
330 & 24 & 0,03 & 13,83 & 0,04 & 38,2 & 0,73 & 0,57 & 78,83 & {$[3]$} \\
270 & 24 & 0,03 & 13,83 & 0,05 & 41,7 & 0,92 & 0,71 & 77,16 & {$[4]$} \\
200 & 24 & 0,05 & 13,83 & 0,07 & 45,6 & 1,29 & 0,98 & 75,55 & \\
180 & 24 & 0,05 & 13,83 & 0,07 & 46,6 & 1,41 & 1,05 & 74,29 & {$[5]$.} \\
120 & 24 & 0,08 & 13,83 & 0,11 & 50,5 & 2,11 & 1,52 & 72,15 & \\
100 & 24 & 0,1 & 13,83 & 0,13 & 52,4 & 2,59 & 1,87 & 72,26 & \\
68 & 24 & 0,16 & 13,83 & 0,19 & 54,3 & 3,86 & 2,74 & 71,01 & {$[6]$.} \\
50 & 24 & 0,22 & 13,83 & 0,26 & 57,4 & 5,28 & 3,7 & 70,09 & \\
\hline
\end{tabular}

\section{Kesimpulan}

Berdasarkan pengukuran dan analisis yang telah dilakukan maka dapat disimpulkan bahwa rangkaian buck converter dengan kontrol IC TL494 sebagai stabilitas tegangan pengisian baterai telah direalisasikan. Hasil pengujian konverter tanpa umpan balik tegangan pada variasi tegangan masukan maksimal $30 \mathrm{~V}$ memiliki penurunan tegangan dari beban $390 \Omega$ ke $50 \Omega$ sebesar $5,528 \mathrm{~V}$. Kemudian pada pengujian konverter dengan umpan balik tegangan, nilai tegangan keluaran dapat dijaga konstan sebesar 13,8 V dengan variasi beban $390 \Omega$ ke $50 \Omega$ dan deviasi rata-rata 0,001 volt. Efisiensi rata - rata buck converter dengan umpan balik tegangan pada variasi beban $390 \Omega$ ke $50 \Omega$ adalah $70,094 \%$. Pengujian dengan menggunakan kontrol umpan balik tegangan pada konverter arus searah tipe buck converter menghasilkan nilai tegangan yang lebih stabil dibandingkan pengujian konverter tanpa umpan balik tegangan.

\section{Referensi}

[1]. A. K. Jain and R. Ayyanar, "Power electronics," pp. 1-68.

2]. D. Doliya, "Feedback and Feedforward Control of Buck Converter with Parasitics," pp. 471-475, 2017.

[3]. D. G. Vutetakis, "10 Batteries," 2001.

[4]. P. Basics and O. Modes, Handbook for Stationary Lead-Acid Batteries. 2012.

5]. M. Otong and R. M. Bajuri, "Maximum Power Point Tracking ( MPPT ) Pada Sistem Pembangkit Listrik Tenaga Angin Menggunakan Buck-Boost Converter," vol. 5, no. 2, 2016.

6]. D. W. Hart, Power Electronics. New York: McGraw-Hill, 2011.

P. Griffith, "Designing Switching Voltage Regulators With the TL494," no. September, pp. 1-29, 2011.

[8]. TOSHIBA, “TLP250,” pp. 1-7, 2017. 